\title{
THE EFFECT OF EMOTIONAL SELF-EFFICACY ON CAREER SATISFACTION WITH SELF-PERCEIVED EMPLOYABILITY AS A MEDIATOR VARIABLE IN Y GENERATION
}

\author{
Kristianto Nico Ari \\ Department of Industrial and Organizational Psychology, Faculty of Psychology, \\ University of Airlangga, Surabaya, Indonesia \\ E-mail: kristianto.nico@gmail.com
}

\begin{abstract}
This study aims to examine whether there is an effect of emotional self-efficacy on career satisfaction and self-perceived employability as mediator variables in $\mathrm{Y}$ Generation. The definition of career satisfaction in this study is based on the explanation of Judge et al. (1995, Seibert et al., 2013) Emotional self-efficacy uses the theory of Kirk, et al. (2011, Pool \& Qualter, 2012). While self-perceived employability uses a theory developed by Rothwell \& Arnold (2007). This research was conducted on permanent employees in various companies with a total of 51 subjects. Data were obtained using survey methods used a scale of career satisfaction (Seibert et al., 2013) which consisted of 12 items, the full version of the scale of emotional self-efficacy (Kirk et al., 2008) consisting of 32 self-perceived items and questionnaires employability (Rothwell \& Arnold, 2007) which consists of 11 items. Data analysis was performed using simple and multiple linear regression methods based on the mediation test analysis techniques of Baron and Kenny (1986). The results of the analysis show that self-perceived employability mediates the effect of emotional self-efficacy on career satisfaction on Y Generation.
\end{abstract}

\section{KEY WORDS}

Career satisfaction, emotional self-efficacy, self-perceived employability, generation $\mathrm{Y}$.

At present, changes in the demographic of the workforce are one of the realities experienced. The demographic change in question is a change in the dominance of generations in the world of work. The world of work is currently dominated by Generation X, this is because the Generation of Baby Boomers will retire (Smola \& Sutton, 2002). On the other hand, Generation $Y$ has also worked and most others are preparing to join the world of work (Lancaster \& Stillman, 2002 in McDonald \& Hite, 2008). Demographically, the Baby Boomers population will decline, the number of Generation $X$ workers will be rivaled by the increasing number of Generation Y. Over time, Generation $Y$ will be the youngest generation that will dominate the workforce in the world. According to Dhawan (2015) he predicts that by 2025, Generation Y will dominate $75 \%$ of the total number of workers in the world. Meanwhile, predictions according to BPS (Central Statistics Agency) in 2020, the population of Indonesia with an age range of 20 to 40 years is around 83 million people, equivalent to $34 \%$ of the total population of Indonesia (Ali \& Purwandi, 2016).

The reality of changing the demographic conditions of the workforce is in fact not easy to manage. It is not easy for Generation $X$ and Baby Boomers to employ Generation $Y$ who have different views, hopes and definitions from them about careers (Lynch, 2008). According to Lynch (2008) Generation $Y$ in general, is more active in leadership than just following orders and controls from superiors. Generation $Y$ is able to be more flexible in building relationships with others and liking work with collaboration methods (Lynch, 2008). Another character that is so attached to Generation $\mathrm{Y}$ is that they have different meanings for career success (Qamariyah, 2016). McDonal and Hite (2008) state that subjectively, Generation $Y$ feels their career success if they can enjoy and feel happy with their position or position at work. The Generation Y's main focus in a career is not just financial but an increase in its personal abilities (Lynch, 2008). So based on this, Generation Y defines that career success for them is reflected in their satisfaction in career satisfaction (Harrington et 
al., 2015). Individual career satisfaction is the main indicator that can measure intrinsic and extrinsic aspects of positive feelings felt by each individual (Greenhaus, et al., 1990).

Nevertheless, there are several opinions that state that Generation $Y$ does not feel satisfied in a career. According to Lockhart (2012), Indonesian and Singapore employees are considered the most dissatisfied workers in the world. Due to the dissatisfaction, Generation $Y$ employees are considered to have low career engagement with the organization because they feel that their expectations of the organization are not fulfilled and cause them not to feel happy with the work they are doing (Karobka, 2015: Ratanjee \& Edmond, 2013). The low workload of Generation $Y$ also has an impact on the turnover rate experienced by the company. The high level of turnover intention can be caused by employee dissatisfaction with his expectations of the organization (Prahadi, 201: Izzati, 2015).

Individual satisfaction in a career is important to study because this aspect is an evaluation of individual subjective career success (Judge et al., 1995). When individuals can achieve success in their career subjectively, it will affect various other psychological constructs. Some studies reveal that subjective career success can reduce turnover intentions (Tschopp \& Grote, 2014; Dyke \& Duxbury, 2010), increase work commitment (Simo, et al., 2010; Dyke \& Duxbury, 2010), and improve subjective well-being ( Ewis, 2015; Keller, et al., 2014; Wiese, et al., 2002) on individuals. Based on that, it is necessary for companies or organizations to pay attention to career satisfaction because when individuals have high career satisfaction will tend to be diligent in undergoing a career path and vice versa if low career satisfaction tends to arise to make plans and strategies and new career behavior (King, 2004, in Seibert et al., 2013). In order for high career satisfaction to be achieved, emotional intelligence is needed to be able to control it. Emotional intelligence is a term to describe emotional adaptive functions, while career satisfaction needed is more subjective so that more is needed is the individual's confidence in his ability to regulate his emotions or commonly called emotional self-efficacy (Pool \& Qualter, 2013). In addition, the tendency of high and low career satisfaction and emotional self-efficacy will lead to a tendency of the ability of individuals to maintain their jobs or even get the desired job or better known as self-perceived employability (Rothwell \& Arnold, 2007).

Based on the explanation above, the authors in this study used self-perceived employability as a mediator variable in connecting emotional self-efficacy and career satisfaction. This research was conducted to prove the relationship of the three variables. Based on the above explanation a question arises, whether the effect of emotional selfefficacy on career satisfaction on $\mathrm{Y}$ Generation is mediated by the role of self-perceived employability.

\section{LITERATURE REVIEW}

Career Satisfaction is interpreted as a form of individual subjective evaluation of the psychological and material conditions obtained from the accumulation of work experience that he lived (Judge et al., 1995 in Seibert et al., 2013). Career satisfaction is part of the career self-regulatory process where individuals can formulate their career goals, develop career plans and implement them, and make efforts for the advancement of their careers. Individuals who have high career satisfaction tend to be diligent in undergoing their career path, while individuals with low levels of career satisfaction tend to make new plans, strategies, and career behaviors (King, 2004, in Seibert et al., 2013).

Emotional Self-Efficacy is a combined term of two concepts, namely Emotional Intelligence and Self-Efficacy. Emotional intelligence is a term used to describe emotional adaptive functions, while self-efficacy is an individual belief in its ability to regulate and take actions needed to produce certain achievements (Bandura, 1997, in Kirk et al., 2008). Emotional self-efficacy is part of emotional intelligence because the character and individual perceptions of emotional functions that are owned are also included in aspects of emotional intelligence (Petrides \& Furnham, 2003, in Kirk, et al., 2008). Kirk, et al. (2011, in Pool \& Qualter, 2012) defines Emotional Self-Efficacy as a belief in one's emotional abilities. Although emotional self-efficacy is included in emotional intelligence, both are not really the 
same (Kirk et al., 2008). Kirk, et al. (2008) also argue that there are aspects of selfperception and character that are not included in emotional self-efficacy. The focus of emotional self-efficacy is the individual's belief in his ability to regulate emotions which is operationalized with 4 abilities in emotional intelligence, namely realizing, using, understanding and managing emotions (Pool \& Qualter, 2013). Someone who has emotional self-efficacy will have the ability to control their emotions (Bandura, et al., 2003., in Pool \& Qualter, 2013).

Self-Perceived Employability at the conceptual level, Rothwell \& Arnold (2007) defines employability as the ability of individuals to maintain the work they have or get the desired job. At the analytical level, this definition is the beginning of measuring employability based on self-rated employability (SRE) (Berntson et al., 2006). SRE discusses individual beliefs about how easy it is to get a new job (Rothwell \& Arnold, 2007), or individual perceptions about the possibility of getting a new job (Berntson et al., 2006).

In general, employability is defined as the ability of individuals to obtain and retain their jobs, or obtain desired jobs (Fugate et al. 2004; Rothwell \& Arnold, 2007). This ability comes from individual knowledge about skills, knowledge of the labor market, and adaptability (Van Dam, 2004). Individuals are said to be employable if they can utilize the factors within themselves effectively to negotiate environmental demands (Fugate, et al., 2004).

\section{METHODS OF RESEARCH}

The subjects in this study were Generation $Y$ aged 21 to 36 years and included permanent employees in a company. Sampling in this study using non-probability techniques with accidental sampling method. The use of this sampling technique allows samples to be taken randomly, so that bias can occur. The choice of subject in his research is sometimes chosen because it is known by the author. To reduce the likelihood, the subject in this study was a subject unknown to the author. Researchers also try to get samples of different types of work environments and diverse ages but still within the range of predetermined criteria.

The number of samples in this study amounted to 51 subjects with a percentage of men $43.13 \%$ namely as many as 22 people and women $56.87 \%$, as many as 29 people. The average subject is 25 years old from various companies, namely, government agencies, state-owned companies, private sector, and independent businesses. The subjects in this study were also dominated by employees of private companies with a total subject of 30 people or $62.5 \%$ of the total subject. The $37.5 \%$ of subjects in this study had a working period of 1 to 2 years.

\section{CONCEPTUAL FRAMEWORK}

Based on empirical studies conducted, it is assumed that the effect of emotional selfefficacy on career satisfaction and self-perceived employability in $\mathrm{Y}$ Generation. The conceptual framework is presented in Figure 1.

Based on the conceptual framework above, the proposed research hypothesis is:

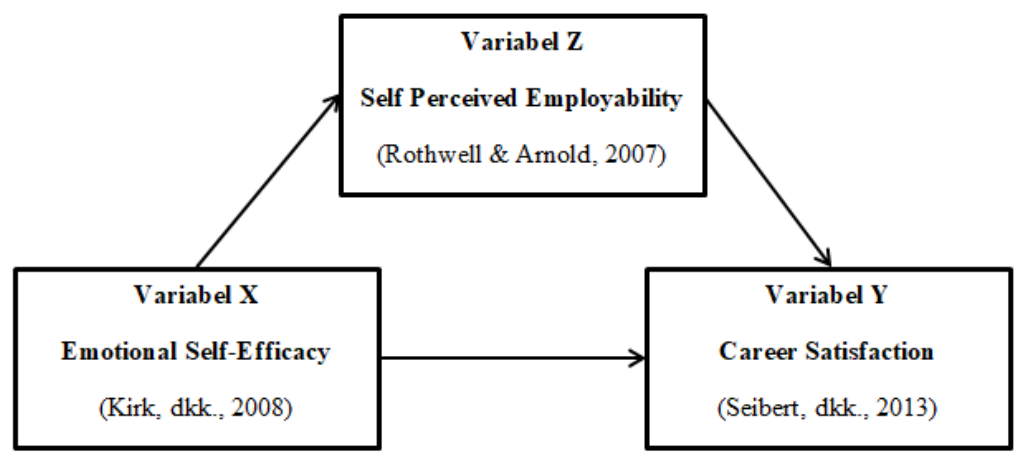

Figure 1 - Conceptual Framework 
Ha: There is an effect of Emotional self-efficacy on Career Satisfaction with Self Perceived Employability as a mediator variable in Generation Y.

Ho: There is no effect of Emotional self-efficacy on Career Satisfaction with Self Perceived Employability as a mediator variable in Generation Y.

\section{RESULT OF STUDY}

Data analysis in this study used the mediation technique of Baron and Kenny (1986) which stated that the procedure for analyzing mediator variables in a simple way can be done through regression tests. However, before conducting a regression analysis, researchers tested the correlation with the research variables. After the correlation test, the researcher conducted a simple linear regression test and continued by conducting multiple linear regression tests.

Table 1 - Correlation Statistics Results

\begin{tabular}{|c|c|c|c|c|}
\hline \multicolumn{2}{|c|}{$\mathrm{n} / \mathrm{n}$} & 1 & 2 & 3 \\
\hline 1 & Emotional Self-Efficacy & 1 & 0,301 & 0,341 \\
\hline 2 & Self Perceived Employability & 0,301 & 1 & 0,533 \\
\hline 3 & Career Satisfaction & 0,341 & 0,533 & 1 \\
\hline
\end{tabular}

Based on the results of the correlation test above, the strength of the relationship between the variables of emotional self efficacy and self-perceived employability is classified as weak, which is equal to 0.301 . The strength of the relationship between the variable emotional self efficacy and career satisfaction is low, which is equal to 0.341 . In contrast, the strength of the relationship between self-perceived employability variables and career satisfaction is classified as moderate with a value of 0.533 . The three correlation results in this study are classified as significant with a significance value of three less than 0.05 at a significance level of $5 \%$. It is seen that the direction of the relationship of all variables is positive. Thus, when the career satisfaction variable increases, the self-perceived employability and career satisfaction variables will also increase. Similar to emotional self efficacy, when the self-perceived employability variable increases, the emotional self-efficacy and career satisfaction variables will also increase.

Table 2 - Results of Regression Analysis

\begin{tabular}{|c|c|c|c|c|c|c|}
\hline No & Regression Model & R Square & Value B & Beta & Sig. & Information \\
\hline 1 & Regression X to Y & 0,116 & 0,172 & 0,341 & 0,014 & Significant \\
\hline 2 & Regression X to Z & 0,091 & 0,138 & 0,301 & 0,016 & Significant \\
\hline \multirow{2}{*}{3} & \multirow{2}{*}{ Regression X and Z to Y } & \multirow{2}{*}{0,320} & $0,100(\mathrm{X})$ & 0,199 & 0,118 & $\begin{array}{c}\text { Not Significant } \\
\text { Significant }\end{array}$ \\
\hline
\end{tabular}

According to Baron and Kenny (1986), the influence of independent variables on the dependent variable with the role of mediator variables will be fulfilled if there are three conditions, namely (1) estimating the estimated predictor value of the dependent variable regression $(\mathrm{Y})$ with an independent variable $(\mathrm{X})$ as a predictor. At this stage, it is expected that the resulting value is significant, (2) estimating the estimated value of the predictor from the mediator variable regression $(Z)$ with an independent variable $(X)$ as a predictor. At this stage, it is expected that the resulting value is also significant, (3) regression of the dependent variable $(\mathrm{Y})$ with the independent variable $(\mathrm{X})$ and the mediator variable $(\mathrm{Z})$ as a predictor. At this stage, the prediction of $Z$ against $Y$ is expected to be a significant value, while the prediction of $X$ against $Y$ is expected to be insignificant. If the three conditions above are met, the magnitude of the effect of the independent variable $(X)$ on the dependent variable $(Y)$ in the third equation must be smaller than the magnitude of the influence of the two in the first equation to get complete mediation.

Based on the table above, it is known that the results of regression analysis are fulfilled in the first and second conditions with estimated predictors of 0.172 and 0.138 and the 
results obtained are significant. Whereas in the third condition, the mediator variable is proven to affect the dependent variable with control of the independent variable. This is indicated by the results that are not significant in the multiple regression model $x$ with $y$ with a significance level that is equal to 0.118 with an estimated predictor value of 0.100 and $Z$ to $Y$ multiple regression with a significance level of 0.000 with an estimated predictor value of 0.533. The estimated value of the predictor $x$ against $y$ in the third equation of 0.099 has proved to be greater than the first equation. Therefore, the research hypothesis which states that there is an influence of emotional self-efficacy on career satisfaction and self-perceived employability as mediator variables in the $Y$ generation is accepted and included in the type of perfect mediation.

\section{DISCUSSION OF RESULTS}

The research conducted this time aims to determine the effect of emotional selfefficacy on career satisfaction through the role of mediators from self-perceived employability in Generation Y. Based on the results of regression analysis obtained in this study, it is known that self-perceived employability can edit the influence of emotional self efficacy towards career satisfaction. This is evidenced by the four requirements in the mediation test Baron and Kenny (1986) fulfilled.

The results of the analysis in the first equation state that ESE has an effect on career satisfaction. But it turns out that ESE's influence on career satisfaction tends to be low. So that it is proven that ESE's relationship with career satisfaction requires other variables to strengthen the relationship between the two. This indicates that even though $Y$ Generation has confidence in its emotional abilities, it will not necessarily be satisfied with its career.

The results obtained in the second equation prove that ESE has an effect on SPE. This is in line with the results of Pool and Qualter (2013) where Generation Y employees who have higher ESE levels see themselves as individuals who are able to be employed. This indicates that the individual's confidence in his emotional abilities influences the selfperceived self-employability of the individual. Individuals who are more confident with their ability to accept, use, understand and manage their emotions will see themselves better to be employed. Individuals who are more confident with their emotional abilities view themselves as effective communicators in interacting with coworkers so that they are able to manage personal networks and be more valued by others (Pool \& Qualter, 2013).

In the third equation, it proves that ESE's influence on career satisfaction will be stronger if it is mediated by SPE. In line with the first and second feelings, even though Generation $Y$ has confidence in their emotional abilities, they will not necessarily be satisfied with their careers. The results of the study prove that when an individual feels confident in his ability to use and manage emotions, he will be easier to interact with his work environment, which guides the individual to feel that he has a better ability to be employed. When the individual's self-perception of the ability to work is good, then he will feel more satisfied in his career.

\section{CONCLUSION AND RECOMMENDATIONS}

Based on a series of analyzes conducted by researchers, it can be concluded that selfperceived employability (SPE) can mediate the effect of emotional self-efficacy (ESE) on career satisfaction. Individuals who believe in their ability to use and manage emotions will have a better perception of their ability to work so that it will increase their satisfaction in a career. Thus, the alternative hypothesis $(\mathrm{Ha})$ in this study was accepted. In line with this, the results of research on Generation $Y$ show a positive correlation between emotional selfefficacy and self-perceived employability and career satisfaction.

In line with the results of the research, the authors propose several suggestions, (1) further research is expected to find out other variables that can be mediators for the relationship of emotional self-efficacy and career satisfaction in Generation $Y$ such as protean career behavior and proactive career behaviors. (2) career satisfaction will be better 
if measured by a multidimensional perspective, namely, dimensions of satisfaction with income, power and status, skill and development and employability, (3) the weakness of this study is to use self-report as a measure of emotional self-efficacy and self -perceived employability, this can actually lead to bias, so further research is expected to be able to conduct an observational method to observe what is done by individuals who have high emotional self-efficacy in their work environment.

\section{REFERENCES}

1. Ali, H., \& Purwandi, L. (2016). Indonesia 2020: Urban middle class millennial. Alva Research Center, 5-7.

2. Berntson, E., Sverke, M., \& Marklund, S. (2006). Predicting perceived employability: human capital or labour market opportunities?. Economic and Industrial Democracy, 27(2), 223-244.

3. Dacre Pool, L. (2013). Emotional self-efficacy, graduate employability, and career satisfaction: Testing the associations. Australian Journal of Psychology, 65(4), 214-223.

4. Dacre Pool, L., \& Qualter, P. (2012). The dimensional structure of the emotional self efficacy scale (ESES). Australian Journal of Psychology, 64(3), 147-154.

5. Dhawan, E. (2012). Busting Gen $Y$ and Gender Myths. Harvard Center Public Leadership, 2-3.

6. Fugate, M., Kinicki, A. J., \& Ashforth, B. E. (2004). Employability: A psycho-social construct, its dimensions, and applications. Journal of Vocational behavior, 65(1), 14-38.

7. Greenhaus, J. H., Parasuraman, S., \& Wormley, W. M. (1990). Effects of race on organizational experiences, job performance evaluations, and career outcomes. Academy of management Journal, 33(1), 64-86.

8. Harrington, B., Van Deusen, F., Fraone, J. S., \& Morelock, J. (2015). How Millennials Navigate Their Careers. Boston College Center for Work \& Familiy.

9. Izzati, N. N., (2015). Makna komitmen organisasi pada generasi y (Skripsi). Surabaya: Universitas Airlangga, Fakultas Psikologi.

10. Kirk, B. A. (2008). Development and preliminary validation of an emotional self-efficacy scale. Personality and Individual Differences, 45(5), 432-436.

11. Korobka, T. (2015). Why 70 percent of millennials are unhappy with their jobs. Sheknows [on-line]. Diakses pada 5 Agustus 2016 http://www.sheknows.com/

12. Lockhart, J. (Maret, 2012). Indonesian millennials are the unhappy with their jobs. Business insider [on-line]. Diakses pada 5 Agustus 2016 dari http://www.businessinsider.com.au/

13. Lynch, A. J. (2008). ROI on generation Y employees. Bottom Line Conversations, 2-8.

14. McDonald, K. S., \& Hite, L. M. (2008). The next generation of career success: Implications for HRD. Advances in Developing Human Resources, 10(1), 86-103.

15. Pool, L.D. (2013). Emotional self-efficacy, graduate employability, and career satisfaction: testing the associations. Australian journal of psychology, 65, 214-223.

16. Prahadi, Y. Y., (2015). Survei: gen y hanya tahan setahun di satu perusahaan. SWA [online]. Diakses pada 5 Agustus 2016 dari http://swa.co.id/swa/trends/management/surveigen-y-hanya-tahan-setahun-di-satu-perusahaan.

17. Rothwell, A., \& Arnold, J. (2007). Self-perceived employability: development and validation of a scale. Personnel Review, 36(1), 23-41.

18. Seibert, S. E., Kraimer, M. L., Holtom, B. C., \& Pierotti, A. J. (2013). Even the best laid plans sometimes go askew: Career self-management processes, career shocks, and the decision to pursue graduate education. Journal of Applied Psychology, 98(1), 169.

19. Smola, W. K., \& Sutton, C. D. (2002). Generational differences: Revisiting generational work values for the new millennium. Journal of organizational behavior, 23(4), 363-382.

20. Van Dam, K. (2004). Antecedents and consequences of employability orientation. European Journal of Work and Organizational Psychology, 13(1), 29-51. 